\title{
Um quarto de século publicando psiquiatria
}

É com muita satisfação e alegria que saúdo o psiquiatra brasileiro através de nossa Revista de Psiquiatria do Rio Grande do Sul. Nascida em 1979, a revista gaúcha publicou nestes 25 anos 943 artigos, 79 exemplares (sendo 3 suplementos) num total de 6.004 páginas. Estes dados dão-nos a dimensão, a responsabilidade científica da mesma e o seu enorme legado.

Cláudio Eizirik, seu primeiro editor, assim descreveu o nascimento da revista, junto à Comissão de História da Sociedade:

"Ao longo de vários meses, de 78 a 79, trabalhamos com entusiasmo, apoiados pela Diretoria da Sociedade de Psiquiatria do Rio Grande do Sul, montando o primeiro número. A idéia que nos norteou, desde o início, foi estruturar uma revista que servisse como um ponto de encontro científico, em que as observações, experiências e indagações que nos trazem nossa especialidade possam ser levantados e debatidos em seus múltiplos aspectos."
"Numa manhã de março de 79, com uma emoção parecida às que se têm em maternidades, vários de nós vimos e pegamos no colo os exemplares da Revista, em meio às impressoras da Grafosul, na General Vitorino. Havia imperfeições, algo faltava aqui ou ali, alguns não gostaram muito da cor (que aos poucos foi sendo melhorada, nos números seguintes); mas enfim, o essencial estava feito: surgia a Revista de Psiquiatria do Rio Grande do Sul."

Durante esses anos, 13 colegas assumiram a editoria da revista e 70 participaram do seu conselho editorial, mas somente conseguimos construir esse patrimônio através da participação efetiva dos psiquiatras. Nossa revista está indexada nos principais indicadores e segue crescendo...

Um boa leitura a todos.

Alfredo Cataldo Neto Presidente da Sociedade de Psiquiatria do Rio Grande do Sul 